\title{
Esthesioneuroblastoma: Summary of Single-center Experiences with Focus on Adjuvant Therapy and Overall Survival
}

\author{
Hammam A. Alotaibi ${ }^{1}$, Stefano M. Priola ${ }^{2,3}$, Anne-Laure Bernat ${ }^{4}$, Faisal Farrash ${ }^{5}$ \\ 1. Research, Prince Sultan Military Medical City, Riyadh, SAU 2. Neurosurgery, University of Toronto, \\ Toronto, CAN 3. Neurosurgery, Sunnybrook Health Sciences Centre, Toronto, CAN 4. Neurosurgery, \\ Lariboisière Hospital, Paris, FRA 5. Neurosurgery, King Faisal Specialist Hospital and Research Center, \\ Riyadh, SAU
}

Corresponding author: Hammam A. Alotaibi, hammam1200@gmail.com

\section{Abstract}

Esthesioneuroblastoma (ENB) is a rare malignant tumor of the nasal cavity. The genetic basis of its development is still under study and has not been fully delineated. It has varying symptoms depending on the lesion's location within the nasal cavity. The most commonly used systems for such lesions are the Kadish staging and Haymes grading systems.

The objectives are to review the most recent published literature evaluating the different treatments/ combination of treatment and assess the most appropriate treatment modality that can provide the longest progression-free survival and overall survival for ENB patients.

Moreover, a look at what the latest literature suggests when it comes to adjuvant treatments and their effect on survival is also key to further the body of knowledge for neurosurgeons, Ears, Nose, and Throat (ENT) physicians and all the different subspecialties that deal and serve these population of patients.

The published literature was reviewed starting from 1990. The focus was made on single-center experiences given their availability and easy access. The most recently published systematic review was used as the benchmark; research published after that was included in this study. The database search in OVID was conducted using the following keywords:

“Esthesioneuroblastoma”, “ENB”, “Olfactory Neuroblastoma”, Nose neoplasm”, skull base neoplasm”, “radiation”, and "resection”. The database search found 17 papers which included 14 single-center reports, one systematic review, and two nationwide multi-center reviews.

Received 04/16/2019

Review began 06/04/2019 Review ended 06/08/2019 Published 06/13/2019

\section{(C) Copyright 2019}

Alotaibi et al. This is an open access article distributed under the terms of the Creative Commons Attribution License CC-BY 3.0., which permits unrestricted use, distribution, and reproduction in any medium, provided the original author and source are credited.
Surgery plus adjuvant radiation therapy appears to provide the best overall survival and progression-free survival especially in patients with high Kadesh grade. On the other hand, surgery alone or biopsy followed with radiation therapy provided the lower progression-free survival and overall survival from time of diagnosis. The role of chemotherapy, however, requires further investigation to assess its potentially harmful effects. The use of surgery as a stand-alone modality of treatment should be cautiously and rarely used in patients with lower staging scores and multiple negative resection margins.

Categories: Otolaryngology, Neurosurgery, Oncology

Keywords: esthesioneuroblastoma, kadesh score, chemotherapy, enb, overall survival, disease free survival, radiation therapy

\section{Introduction And Background}


Esthesioneuroblastoma (ENB) is a rare malignant tumor of the nasal cavity with distinct clinicopathologic features, multiple facets, and differing clinical behavior [1]. It originates from olfactory cells and also has a neural crest origin. Although it is a rare tumor, it has the potential for aggressive growth and the propensity for regional metastasis [2]. Early discovery and aggressive management play a key role in a patient's survival and quality of life [3]. ENB was described in 1924, and since then different institutions have developed various protocols for treatment whether it is surgical, radiation, chemo or a combination of these treatment modalities [4]. In modern practice, multimodality/multidisciplinary therapy appears to be the approach of choice [5]. There has not been extensive research on the genetic basis of ENB in recent years but sonic-hedgehog gene has been implicated recently in the development of the tumor. Further investigation is necessary to determine what other genes might be responsible for tumor development [6].

Symptoms of ENB vary depending on the location of the tumor and the extent of the disease and the stage at presentation. The most common symptoms are unilateral nasal obstruction, nasal bleeding, headache, facial pain, and a decreased sense of smell. Extension of the tumor to the eyes or the cranial cavity and the nasal cavity can lead to symptoms related to these areas. Serous otitis media can develop due to the obstruction of the eustachian tube. Sinonasal symptoms are the most common in this condition, and they mimic the symptoms of inflammatory disease in the area and could be confused as such, leading to misdiagnosis delaying effective treatment [7].

It is worth noting that $20 \%$ of patients who present with ENB will have neck metastasis so it is important for proper diagnosis to take a good history and perform a focused physical exam with an emphasis on the neck examination. Nasal endoscopy is then performed to locate the tumor, stage it and obtain a biopsy [8].

When suspecting ENB the initial test that should be performed is a high-resolution computerized tomography (CT) scan. This allows for superior delineation of bony structures and whether they are intact or broken. It is of critical importance to observe the orbit, skull base, septum, and palate. High-resolution CT is the imaging modality used initially. Each patient with suspected ENB needs to undergo a CT scan and a magnetic resonance imaging (MRI) scan as part of the standard imaging procedure. This is critical to evaluate lesion extent, and involvement of the surrounding structures like the orbit, skull base, dura and brain parenchyma. CT of the neck, chest, and abdomen is the next step to evaluate the possibility of metastasis. Positron emission tomography (PET) scan is an option to investigate distant metastasis as well [9-10].

Several staging and grading systems have been developed to assess ENB. Hyams grading system is used for prognosis and grading while the Kadish system is for staging the disease. These are the most widely used systems in modern day literature. The difficulty in validating any staging system in the case of ENB is due to the low incidence of disease among other variables [11-12].

\section{Review}

\section{Methods}

This is a literature summary designed to report relevant center experience concisely and clearly to qualitatively report findings on which of the currently used protocols provide the lowest mortality and morbidity in clinical trials conducted from 1990 to January 2019. The objective of this study is to report the treatment option that has the best progression-free survival and overall survival. All clinical trials published since 1990 until January 2019 were selected. Studies were required to be written in English and include a sample of adult males and females. Databases used include PubMed, Medline, the Cochrane Collaboration. Keywords were: 


\section{Cureus}

“Esthesioneuroblastoma”, “ENB”, “Olfactory Neuroblastoma”, Nose neoplasm”, skull base neoplasm”, “radiation”, and "resection”. The search yielded 684 articles. Limitations used were: published after 1990, English language, and clinical trials. Results were excluded if written before 1990, written in languages other than English and if the sample under study is not adult males or females. Studies that did not address the question directly were also excluded.

The search yielded seventeen papers that were included in this review. The criteria to accept papers was based on the clear reporting of outcomes post-intervention. Fourteen single-center experiences, one systematic review, two nationwide multiple center retrospective reviews were included. Studies that analyzed the same sample and reported the same prognostic variables were excluded from the summary but added in the discussion as relevant. This exclusion is to limit redundancy in analyzing findings and to avoid exaggerating results. Data reported in this review are summarized in Table 1.

\begin{tabular}{|c|c|c|c|c|c|c|c|}
\hline Study ID & Design & Sample & Staging/metastasis & Treatment option & Follow up & survival & commentary \\
\hline $\begin{array}{l}\text { Ow, et al., } \\
2013 \text { [13] }\end{array}$ & $\begin{array}{l}\text { Retrospective } \\
\text { review 1992- } \\
2007\end{array}$ & $\begin{array}{l}\mathrm{N}=70 \\
\text { ENB } \\
\text { patients }\end{array}$ & $\begin{array}{l}77 \% \text { were T-3 or T-4 } \\
38 \% \text { were modified } \\
\text { Kadesh B or C }\end{array}$ & $\begin{array}{l}90 \% \text { received } \\
\text { surgical resection } \\
66 \% \text { received } \\
\text { post-operative } \\
\text { radiation or } \\
\text { chemotherapy }\end{array}$ & $\begin{array}{l}\text { Median } \\
\text { follow up: } \\
91.4 \\
\text { months } \\
\text { (7.6 years) }\end{array}$ & $\begin{array}{l}48 \% \\
\text { developed } \\
\text { recurrent } \\
\text { disease. } \\
\text { Median time } \\
\text { to recurrence: } \\
6.9 \text { years. }\end{array}$ & $\begin{array}{l}\text { Surgery } \\
\text { alone: } 87.9 \\
\text { months } \\
\text { survival } \\
\text { Surgery + } \\
\text { chemo/ } \\
\text { radiation: } \\
218.5 \text { months } \\
\text { survival. }\end{array}$ \\
\hline $\begin{array}{l}\text { Herr et al., } \\
2014 \text { [14] }\end{array}$ & $\begin{array}{l}\text { Retrospective } \\
\text { chart review } \\
1997-2013\end{array}$ & $\begin{array}{l}\mathrm{N}=22 \\
\mathrm{ENB} \\
\text { patients }\end{array}$ & $\begin{array}{l}\text { Kadesh stage B: } 10 \\
\text { patients, stage C: } \\
12 \text { patients } 27 \% \\
\text { developed regional } \\
\text { metastasis }\end{array}$ & $\begin{array}{l}\text { All received CFR+ } \\
\text { radiation therapy } \\
\text { With/without } \\
\text { chemo }\end{array}$ & $\begin{array}{l}\text { Average } \\
\text { follow up: } \\
73 \text { months }\end{array}$ & $\begin{array}{l}5 \text { years } \\
\text { disease free } \\
\text { and overall } \\
\text { survival: } \\
86.4 \% \text { and } \\
95.2 \% \\
\text { respectively }\end{array}$ & $\begin{array}{l}\text { Photon beam } \\
\text { radiation } \\
\text { showed lower } \\
\text { toxicity than } \\
\text { other radiation } \\
\text { options. }\end{array}$ \\
\hline $\begin{array}{l}\text { Tajudeen et } \\
\text { al., } 2014 \\
\text { [15] }\end{array}$ & $\begin{array}{l}\text { Retrospective } \\
\text { review 2002- } \\
2013\end{array}$ & $\begin{array}{l}\mathrm{N}=41 \\
\text { (36 } \\
\text { included) } \\
\text { ENB } \\
\text { patients } \\
\text { UCLA } \\
\text { medical } \\
\text { center }\end{array}$ & $\begin{array}{l}\text { Kadesh A: } 2 \text { Kadesh } \\
\text { B: } 15 \text { Kadesh C: } 20 \\
\text { Kasesh D: } 4\end{array}$ & $\begin{array}{l}\text { CFR: } 8 \text { pts. TFR: } \\
20 \text { pts. ECR: } 8 \text { pts. }\end{array}$ & $\begin{array}{l}\text { Mean } \\
\text { follow up: } \\
31.5 \\
\text { months }\end{array}$ & $\begin{array}{l}5 \text { years } \\
\text { recurrence } \\
\text { free and } \\
\text { overall } \\
\text { survival: } 54 \% \\
\text { and } 82 \% \\
\text { respectively }\end{array}$ & $\begin{array}{l}\text { All methods } \\
\text { showed } \\
\text { comparable } \\
\text { outcomes in } \\
\text { survival }\end{array}$ \\
\hline $\begin{array}{l}\text { Yin et al., } \\
2015 \text { [16] }\end{array}$ & $\begin{array}{l}\text { Retrospective } \\
\text { review of } \\
\text { center } \\
\text { records } \\
\text { 1979-2014 }\end{array}$ & $\begin{array}{l}\mathrm{N}=111 \\
\text { patients } \\
\text { with } \\
\text { ENB }\end{array}$ & $\begin{array}{l}\text { Stage A: } 1 \text { pts. } \\
\text { Stage B: } 23 \text { pts. } \\
\text { Stage C: } 87 \text { pts. } \\
\mathrm{N}+: 27 \text { pts. }\end{array}$ & $\begin{array}{l}\text { Surgery + RT } \pm \\
\text { Chemo: } 51 \text { pts. } \\
\text { Preoperative RT + } \\
\text { surgery + Chemo: } \\
11 \text { pts. RT + } \\
\text { chemo: } 46 \text { pts. } \\
\text { Surgery } \pm \text { chemo: } \\
3 \text { pts. }\end{array}$ & $\begin{array}{l}\text { Mean } \\
\text { follow up } 5 \\
\text { years }\end{array}$ & $\begin{array}{l}\text { Stage A: } 19 \\
\text { years Stage } \\
\text { B: (OS: } 81 \% \text {, } \\
\text { DFS: } 71 \%) \\
\text { Stage C: (OS: } \\
71 \% \text {, DFS: } \\
49 \%) 8\end{array}$ & $\begin{array}{l}\text { preoperative } \\
\text { RT + surgery } \\
\text { indicated best } \\
\text { survival. }\end{array}$ \\
\hline
\end{tabular}




\section{Cureus}

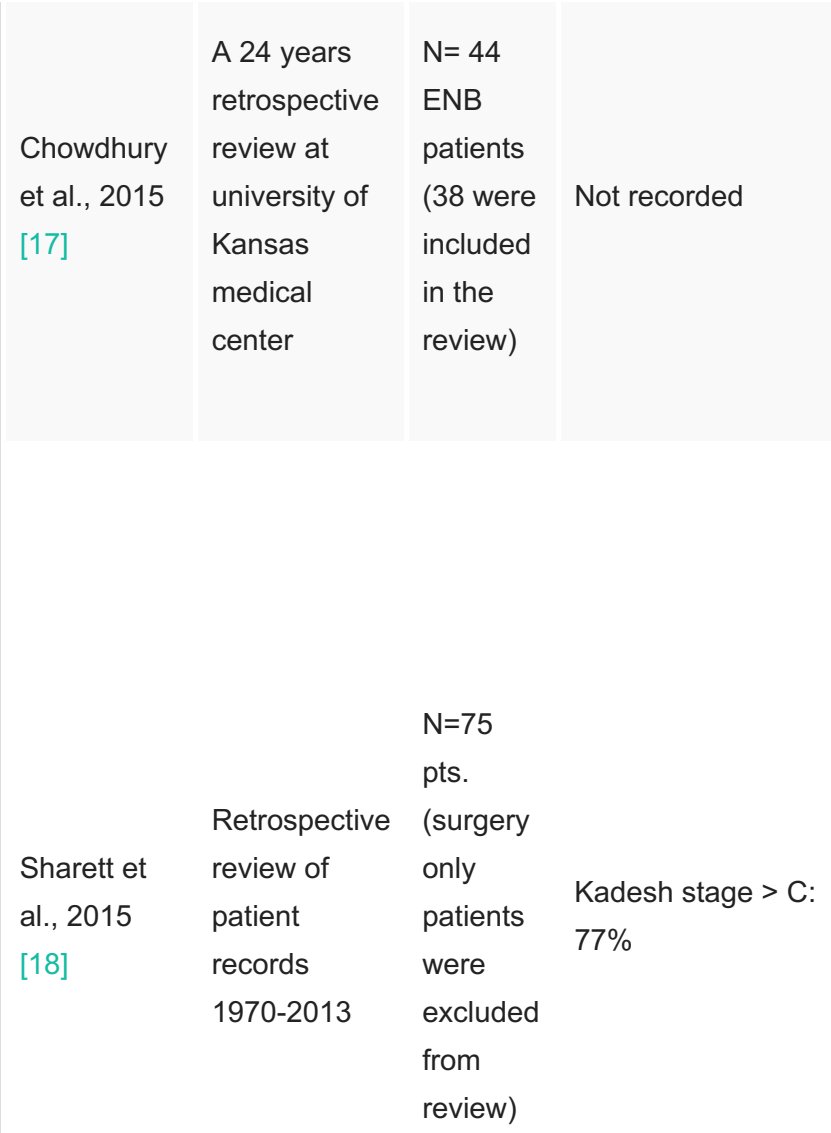

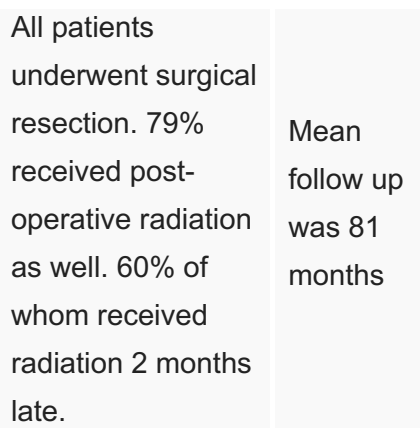

$\begin{array}{ll}\text { A } 10 \text { weeks } & \\ \text { delay of } & \text { Delayed } \\ \text { radiation } & \text { radiation } \\ \text { therapy post- } & \text { could } \\ \text { surgical } & \text { potentially } \\ \text { resection } & \text { increase risk } \\ \text { increased } & \text { of metastasis } \\ \text { metastasis } & \\ \text { risk by } 50 \% . & \end{array}$

Combined

therapy

provides the

5 and $10 \quad$ best predictor

years OS of survival and

rates were disease free

$87 \%$ and $74 \%$ time.

respectively. Exclusion of

Median

received radiation

therapy. $88 \%$ post

operatively. $12 \%$

preoperatively.

$26.6 \%$ received

chemotherapy

follow up:

105

months

$93 \%$ and $81 \%$

were free

patients who

received

from distant

surgery only

metastasis at

5 and 10

is problematic

and requires

years follow

up

respectively.

explanation

by the authors

of what

happened to

them at follow

up.

Retrospective

review of

patient data

Lapierre et

al., 2016

at Lyon Sud

$\mathrm{N}=10$

Kadesh stage C:

University

pts.

$90 \%$
Hospital

(France)

1993-2015
Agarwal et

al., 2017

[20]
[19]

$\begin{array}{llll} & & \mathrm{N}=109 & \\ \text { Agarwal et } & \text { Retrospective } & \text { pts (only } & \\ \text { al., } 2017 & \text { review at } & 45 \text { met } & \text { Kadesh stage B or } \\ \text { 20] } & \text { Mayo clinic, } & \text { the } & \text { C (selection criteria) } \\ & \text { Rochester } & \begin{array}{l}\text { inclusion } \\ \text { criteria) }\end{array} & \end{array}$

Surgical resection

+ radiation therapy

AR: 22 pts.

Mean

Surgical resection

follow-up

with no adjuvant

was 103.4

radiation NAR: 9

pts. $\pm 60.3$

months

\section{Median \\ follow up \\ was 136 \\ months}

Ten-year

overall

survival was

$90 \%$. Five-

and ten-year

progression-

free survival

were $70 \%$ and

$50 \%$

AR: 9 dead, 7

secondary to

ENB at last

follow up.

NED: 8 NAR:

5 developed

recurrence at

mean $50.8^{+/}$-

50.9 months.

Received

radiation. All

were alive at
None of the

patients

received

nodal

irradiation

$50 \%$ of

patients had

disease

recurrence

Little toxicity

incurred due

to immediate

radiation.

Patients

undergoing

delayed

radiation

developed

recurrence at

time of

salvage

surgery were 


\section{Cureus}

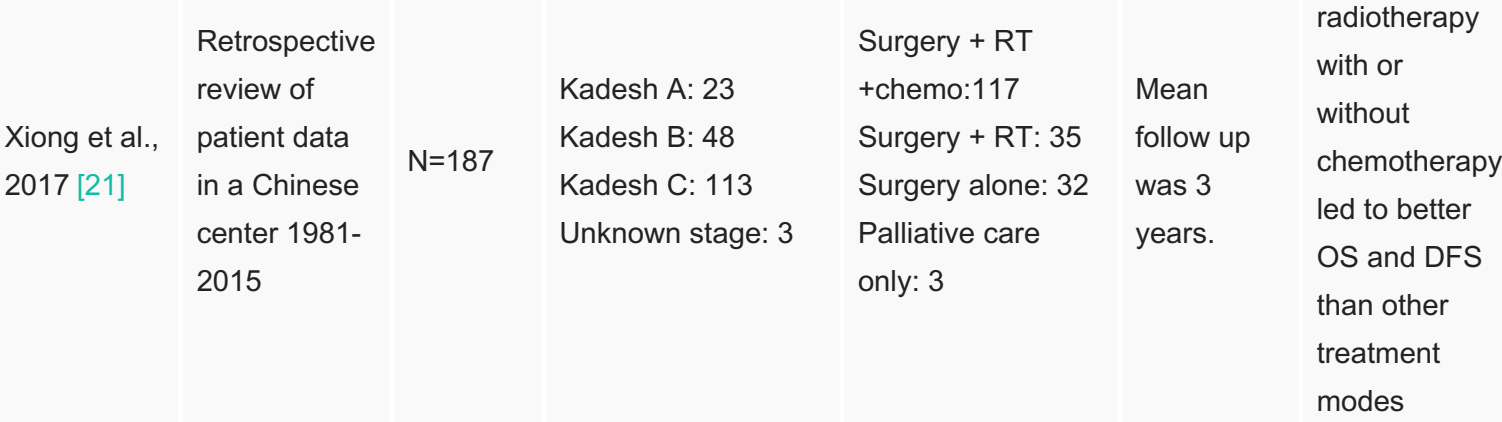

Retrospective

\section{Nakagawa}

et al., 2017

[22]

(Multicenter, Japan)

$\begin{array}{ll} & \text { between } \\ & 2008-2016\end{array}$

review of

patient

records from

10 centers in

Japan

2008-2016
Retrospective

review of

Lui et al., 2017 [23]
$\mathrm{N}=2210$

M $12 \mathrm{~F}$
Dulguerov staging at presentation was:

T1: 6 patients T2: 9 patients $\mathrm{T} 3: 5$ patients $\mathrm{T} 4: 2$ patients
Surgery + RT: 33

Kadesh A: 7

Kadesh: B: 8

Kadesh C: 27

rt + surgery: $2 p t s$
$\mathrm{N}=42$ single center from 19862016 unilateral

resection via EEA

was performed in

12 patients

bilateral resection via EEA was done in 10 patients

Post-operative radiotherapy was done in 20 patients last follow up.

NED: 6

all alive at the last follow up.

Surgery and

combined

therapy is the

optimal

modality of

treatment for

patients with

ENB. Follow

up is short

compared to

the literature

Not receiving

combined

modality was

an

independent

factor for poor

OS and DFS.

Multilayer

resection with

EEA is a safe

method to

treat ENB.

Surgery +

radiotherapy

provides an

excellent

combination

for the

treatment.

Kaplan-Meier

5 and 10

years overall

Surgery and

survival: $83 \%$

radiation

and $72 \%$

therapy

respectively. provide the

Kadesh $\mathrm{C}$ is

Median

most

6 pts Preoperative

follow up:

worse than

favorable

87 months

Kadesh A/b

outcomes

combined:

even with

$57 \%$ vs $88 \%$

locally

Kaplan-Meier

10 years

advanced

disease.

overall

survival

Average 


\section{Cureus}

\begin{tabular}{|c|c|c|c|c|c|c|c|}
\hline $\begin{array}{l}\text { Palejwala et } \\
\text { al., } 2017 \\
{[24]}\end{array}$ & $\begin{array}{l}\text { Retrospective } \\
\text { review of } \\
\text { medical } \\
\text { records at } \\
\text { single center } \\
2006-2016\end{array}$ & $N=8$ & $\begin{array}{l}\text { Kadesh A: } 4 \\
\text { Kadesh C, D: } 4\end{array}$ & $\begin{array}{l}\text { Kadesh A: } \\
\text { endoscopic } \\
\text { approach Kadesh } \\
\text { C, D: craniofacial } \\
\text { approach All } \\
\text { patients received } \\
\text { RT post-surgery. }\end{array}$ & $\begin{array}{l}\text { Average } \\
\text { follow up } \\
\text { was } 60.4 \\
\text { months }\end{array}$ & $\begin{array}{l}\text { progression } \\
\text { free interval } \\
\text { was } 57 \\
\text { months. } \\
\text { Overall } \\
\text { survival was } \\
88 \% \text { at the } \\
\text { end of the } \\
\text { study. }\end{array}$ & $\begin{array}{l}\text { Complications } \\
\text { occurred in } \\
\text { high Kadesh } \\
\text { stages only. }\end{array}$ \\
\hline $\begin{array}{l}\text { Carey et al., } \\
2017 \text { [25] }\end{array}$ & $\begin{array}{l}\text { Retrospective } \\
\text { review of } \\
\text { NCDB } \\
\text { database for } \\
\text { ENB patients } \\
\text { in the united } \\
\text { states }\end{array}$ & $\begin{array}{l}\mathrm{N}=1225 \\
(1118 \\
\text { were } \\
\text { included } \\
\text { in the } \\
\text { analysis) }\end{array}$ & $\begin{array}{l}\text { Kadesh (n): A: } 225 \\
\text { B: } 167 \text { C: } 597 \text { D: } 31 \\
\text { Unknown: } 98\end{array}$ & $\begin{array}{l}\text { Surgery: } 242 \\
\text { Radiation: } 19 \\
\text { Chemo: } 22 \\
\text { Surgery+ } \\
\text { radiation: } 383 \\
\text { Surgery+ chemo+ } \\
\text { radiation: } 182 \\
\text { Surgery+ chemo: } \\
19 \text { Radiation then } \\
\text { surgery: } 12 \\
\text { Radiation before } \\
\text { and after surgery: } \\
3 \text { Radiation before } \\
\text { and after surgery + } \\
\text { chemo: } 2\end{array}$ & $\begin{array}{l}\text { Multivariate } \\
\text { analysis of } \\
\text { NCDB. } \\
\text { Follow up } \\
\text { time not } \\
\text { specified. }\end{array}$ & $\begin{array}{l}\text { the } 5 \text {-year } \\
\text { overall } \\
\text { survival was } \\
76.2 \%\end{array}$ & $\begin{array}{l}\text { surgery } \\
\text { followed by } \\
\text { radiation } \\
\text { without } \\
\text { chemotherapy } \\
\text { had improved } \\
\text { all-cause } \\
\text { mortality. } \\
\text { Surgery } \\
\text { followed by } \\
\text { chemotherapy } \\
\text { has worse } \\
\text { overall } \\
\text { survival for } \\
\text { Kadesh C pts. }\end{array}$ \\
\hline $\begin{array}{l}\text { Gallia et al., } \\
2018 \text { [26] }\end{array}$ & $\begin{array}{l}\text { Retrospective } \\
\text { chart review } \\
\text { of } 20 \text { patients } \\
\text { with ONB } \\
\text { between } \\
2006 \text { and } \\
2017\end{array}$ & $\mathrm{~N}=20$ & Not reported. & $\begin{array}{l}\text { Surgery: } 20 \\
\text { Surgery + } \\
\text { radiotherapy: } 19 \\
\text { Surgery + } \\
\text { radiotherapy + } \\
\text { post operative } \\
\text { chemotherapy: } 5\end{array}$ & $\begin{array}{l}\text { Mean } \\
\text { follow up: } 5 \\
\text { years }\end{array}$ & $\begin{array}{l}\text { At } 5 \text { years } 19 \\
\text { pts were } \\
\text { alive. } 1 \mathrm{pt} \\
\text { died from } \\
\text { unrelated } \\
\text { illness. } \\
\text { Overall } \\
\text { survival: } \\
\text { 92.2\% } \\
\text { Disease } \\
\text { specific } \\
\text { survival: } \\
100 \% \\
\text { Recurrence } \\
\text { free survival: } \\
\text { 92.9\% }\end{array}$ & $\begin{array}{l}\text { The findings } \\
\text { support the } \\
\text { continued use } \\
\text { of endoscopic } \\
\text { procedures to } \\
\text { treat ONB. }\end{array}$ \\
\hline
\end{tabular}

\section{TABLE 1: Summary of included studies}

AR: Adjuvant radiation, CFR: craniofacial resection, DFS: Disease-free survival, ECR: Expanded-endoscopic, endonasal approach, EEA: Endoscopic endonasal approach, ENB: Estheisioneuroblastoma, F: Female, M: Male, n: Sample size, NAR: Neoadjuvant radiation therapy, NCDB: National Cancer Database, NED: No evidence of disease, ONB: olfactory neuroblastoma, OS: Overall survival, Pts: Patients, RT: Radiation therapy, TFR: transfacial resection without craniotomy. 
ENB is a rare condition that affects the nasal cavity. Due to the rarity of the disease and different treatment modalities in different centers, generalizations about single center experiences is difficult. Moreover, there is heterogeneity that comes with the findings that must be kept into consideration while evaluating the results. In this review, one theme can be ascertained very quickly, which is the clear trend towards far superior overall survivability and disease-free survival with multimodal interventions; namely surgical resection followed by radiation therapy [18-23]. In all studies included in this review, this finding has been consistent regardless of the resection type. This finding becomes more apparent with higher disease stages as surgery followed by radiation therapy showed longer disease-free progression in Kadesh stage C in particular [25-28].

It is worth noting that in two studies delayed administration of radiation post-surgical resection was associated with a higher probability of disease recurrence and metastasis suggesting the necessity of fast and aggressive introduction of adjuvant radiation therapy early after surgical resection $[15,19,21]$. When comparing two groups, the first receiving radiation therapy post-surgery and the other group receiving it six weeks to two months' post-surgery, the authors found that although the patients receiving the radiation therapy immediately postsurgery had slightly higher levels of toxicity than the patients who did not receive it promptly, they did better than the delayed group in the disease-free time and time to recurrence with metastasis [20].

One very important aspect we think needs further research is whether the introduction of nasal endoscopic surgical techniques as compared to conventional surgical techniques for ENB treatment accelerated the healing process opening the door for a timely use of

adjuvant radiation therapy which could lead to an even better outcome in terms of disease-free survival. The current literature does not show any significant difference between surgical techniques on their own in terms of outcome [15]. However, it would be worth investigating whether techniques with better healing time coupled with the rapid introduction of radiation therapy would be superior to other techniques.

As for using radiation and when to use it pre or post-surgical resection, most studies in this review used radiation post-surgical resection, however, the reasoning for this choice is not clear. It is true that this is the standard practice by ENT and neurosurgical teams, however, the basis for this choice is not challenged by other options thus far. An example of a challenging outcome would be Yin et al. (2016) who used radiation therapy before surgical resection and found the results to be superior to using it after surgery in terms of disease-free survival [16]. This study given its sample size has a significant weight in begging the question of when radiation needs to be done pre or post-surgery for the best overall and progression-free survival.

\section{Conclusions}

ENB is a rare olfactory neoplasm that requires careful evaluation and prompt diagnosis. Aggressive treatment is necessary to improve patient disease-free and overall survival. This review concludes that surgical resection followed by radiation therapy provides the best disease-free survival and overall survival. The role of chemotherapy post surgery is potentially harmful to disease-free survival and overall survival and thus should be discouraged until further research is conducted to ascertain the degree of benefit and harm to patients.

\section{Additional Information \\ Disclosures}

Conflicts of interest: In compliance with the ICMJE uniform disclosure form, all authors 
declare the following: Payment/services info: All authors have declared that no financial support was received from any organization for the submitted work. Financial relationships: All authors have declared that they have no financial relationships at present or within the previous three years with any organizations that might have an interest in the submitted work. Other relationships: All authors have declared that there are no other relationships or activities that could appear to have influenced the submitted work.

\section{References}

1. Jethanamest D, Morris LG, Sikora AG, Kutler DI: Esthesioneuroblastoma. Arch Otolaryngol Head Neck Surg. 2007, 133:276-280. 10.1001/archotol.133.3.276

2. Faragalla H, Weinreb I: Olfactory neuroblastoma: a review and update. Adv Anat Pathol. 2009, 16:322-331. 10.1097/pap.0b013e3181b544cf

3. Mclean JN, Nunley SR, Klass C, Moore C, Susan M, Peter ASJ: Combined modality therapy of esthesioneuroblastoma. Otolaryngol Head Neck Surg. 2007, 136:998-1002. 10.1016/j.otohns.2006.11.051

4. Cantrell RW, Ghorayeb BY, Fitz-Hugh GS: Esthesioneuroblastoma: diagnosis and treatment. Ann Otol Rhinol Laryngol. 1977, 86:760-765. 10.1177/000348947708600608

5. Petruzzelli G, Howell J, Pederson A, et al.: Multidisciplinary treatment of olfactory neuroblastoma: patterns of failure and management of recurrence. Am J Otolaryng. 2015, 36:547-553. 10.1016/j.amjoto.2015.02.008

6. Mao L, Xia Y-P, Zhou Y-N, et al.: Activation of sonic hedgehog signaling pathway in olfactory neuroblastoma. Oncology. 2009, 77:231-243. 10.1159/000236047

7. Nichols A, Chan A, Curry W, Barker F, Deschler D, Lin D: Esthesioneuroblastoma: The Massachusetts eye and ear infirmary and Massachusetts general hospital experience with craniofacial resection, proton beam radiation, and chemotherapy. Skull Base. 2008, 18:327337. 10.1055/s-2008-1076098

8. Gore MR, Zanation AM: Salvage treatment of late neck metastasis in esthesioneuroblastoma . Arch Otolaryngol Head Neck Surg. 2009, 135:1030-1034. 10.1001/archoto.2009.143

9. Dulguerov P, Allal AS, Calcaterra TC: Esthesioneuroblastoma: a meta-analysis and review. Lancet Oncol. 2001, 2:683-690. 10.1016/s1470-2045(01)00558-7

10. Pickuth D, Obrunner SHH-K, Spielmann RP: Computed tomography and magnetic resonance imaging features of olfactory neuroblastoma: an analysis of 22 cases. Clin Otolaryngol Allied Sci. 1999, 24:457-461. 10.1046/j.1365-2273.1999.00295.x

11. Van Gompel JJ, Giannini C, Olsen KD, et al.: Long-term outcome of esthesioneuroblastoma: hyams grade predicts patient survival. J Neurol Surg B. 2012, 73:331-336. 10.1055/s-00321321512

12. Kadish S, Goodman M, Wang CC: Olfactory neuroblastoma-a clinical analysis of 17 cases . Cancer. 1976, 37:1571-1576.

13. Ow TJ, Hanna EY, Roberts DB, et al.: Optimization of long-term outcomes for patients with esthesioneuroblastoma. Head Neck. 2014, 36:524-530. 10.1002/hed.23327

14. Herr M, Sethi R, Meier J, et al.: Esthesioneuroblastoma: an update on the massachusetts eye and ear infirmary and massachusetts general hospital experience with craniofacial resection, proton beam radiation, and chemotherapy. J Neurol Surg B. 2014, 75:058-064. 10.1055/s-00331356493

15. Tajudeen B, Arshi A, Suh J, et al.: Esthesioneuroblastoma: an update on the UCLA experience 2002-2013. J Neurol Surg B. 2014, 75:074. 10.1055/s-0034-1370480

16. Yin Z, Luo J, Gao L: Treatment modalities and outcomes of esthesioneuroblastoma in a single institution. Int J Radiat Oncol Biol Phys. 2015, 93:296. 10.1016/j.ijrobp.2015.07.1294

17. Chowdhury N, Mark J, Beahm D, Chamoun R, Tsue T, Camarata P, Hoover L: Long-term outcomes following surgical resection of skull base esthesioneuroblastomas. J Neurol Surg B. 2015, 76:085. 10.1055/s-0035-1546552

18. Sharrett JM, Jiang W, Mohamed AS, et al.: Multimodality management of patients with esthesioneuroblastoma. Int J Radiat Oncol Biol Phys. 2015, 93:E349. 10.1016/j.ijrobp.2015.07.1436

19. Lapierre A, Selmaji I, Selmaji H, Brahmi T, Yossi S: Esthesioneuroblastoma: a single institution's experience and general literature review. Cancer Radiother. 2016, 20:783-789. 


\subsection{6/j.canrad.2016.05.015}

20. Agarwal V, Hughes J, Foote R, et al.: Delaying post-operative radiation in low grade esthesioneuroblastoma: Is it worth the wait?. J Neurol Surg B. 2017, 78:1-156. 10.1055/s0037-1600638

21. Xiong L, Zeng X-L, Guo C-K, Liu A-W, Huang L: Optimal treatment and prognostic factors for esthesioneuroblastoma: retrospective analysis of 187 Chinese patients. BMC Cancer. 2017, 17:254. 10.1186/s12885-017-3247-z

22. Nakagawa T, Kodama S, Kobayashi M, et al.: Endoscopic endonasal management of esthesioneuroblastoma: a retrospective multicenter study. Auris Nasus Larynx. 2018, 45:281285. 10.1016/j.anl.2017.05.001

23. Lui A, Parvathaneni U, Laramore GE, et al.: Management and long term outcomes of esthesioneuroblastoma at a single institution. Int J Radiat Oncol Biol Phys. 2017, 99:355-356. 10.1016/j.ijrobp.2017.06.1451

24. Palejwala SK, Sharma S, Le CH, Chang E, Lemole M: Complications of advanced kadish stage esthesioneuroblastoma: single institution experience and literature review. Cureus. 2017, 9:E1245. 10.7759/cureus.1245

25. Carey RM, Godovchik J, Workman AD, et al.: Patient, disease, and treatment factors associated with overall survival in esthesioneuroblastoma. Int Forum Allergy Rhinol. 2017, 7:1186-1194. 10.1002/alr.22027

26. Gallia G, Asemota A, Blitz A, Lane A, Koch W, Reh D, Ishii M: Endonasal endoscopic resection of olfactory neuroblastoma: an 11-year experience. J Neurol Surg B. 2019, 80:S1-S244. 10.1055/s-0039-1679591

27. Rocchi A, Malagutti N, Faita A, et al.: Multidisciplinary approach in advanced case of nasal esthesioneuroblastoma: a case report and review of literature. Int J Health Sci. 2014, 2:73-80. 10.15640/ijhs.v2n4a6

28. Ilson S, Schorwer M, Frelinghuysen M, Platin E, Delgado C, Mucientes F: Esthesioneuroblastoma metastatic to the neck and lung: a case report and review of the literature. Memo. 2015, 8:152-155. 10.1007/s12254-015-0216-6 